\title{
Orbital metastasis from prostate cancer
}

\author{
Mashrafi Ahmed, Tahmina Begum
}

Texas Tech University, Amarillo, Texas, USA

\section{Correspondence to} Dr Mashrafi Ahmed, mashrafi.ahmed@ttuhsc.edu

Accepted 28 July 2015

\section{CrossMark}

\section{To cite: Ahmed M,} Begum T. BMJ Case Rep Published online: [please include Day Month Year] doi:10.1136/bcr-2015211447

\section{DESCRIPTION}

An 82-year-old man presented with proptosis, progressive throbbing pain and blurry vision in the right eye, gradually worsening over the past 3 weeks. The patient was diagnosed with prostate cancer and had undergone a radical prostatectomy nearly 14 years prior. After the surgery, his prostate-specific antigen (PSA) levels remained normal on regular follow-up, although he did not visit an oncologist for the past 4 years. He did not report bony pain, weight loss or headache. His thyroid function was normal. CT of the orbit showed a soft tissue mass within the right orbit, with bony destruction of the greater wing of sphenoid, and optic nerve compression (figures 1 and 2, yellow arrow). CT of the abdomen and pelvis showed osteosclerotic lesions involving multiple vertebral bodies and the right iliac bone. His PSA level was $4.4 \mathrm{ng} / \mathrm{mL}$. A biopsy from the iliac bone confirmed prostatic adenocarcinoma. The patient was started on androgen suppression with leuprolide and methylprednisolone, and radiotherapy was initiated. His symptoms improved initially, but he started to develop more lesions in the right frontal lobe. Considering his age and the aggressive nature of the disease, the patient decided to opt for hospice care. He died a couple of months later.

Metastasis to the orbit from a solid tumour is rare. Among the different malignancies, breast cancer most commonly metastasises to the orbit. ${ }^{1}$ Prostate cancer was found to be the second or third

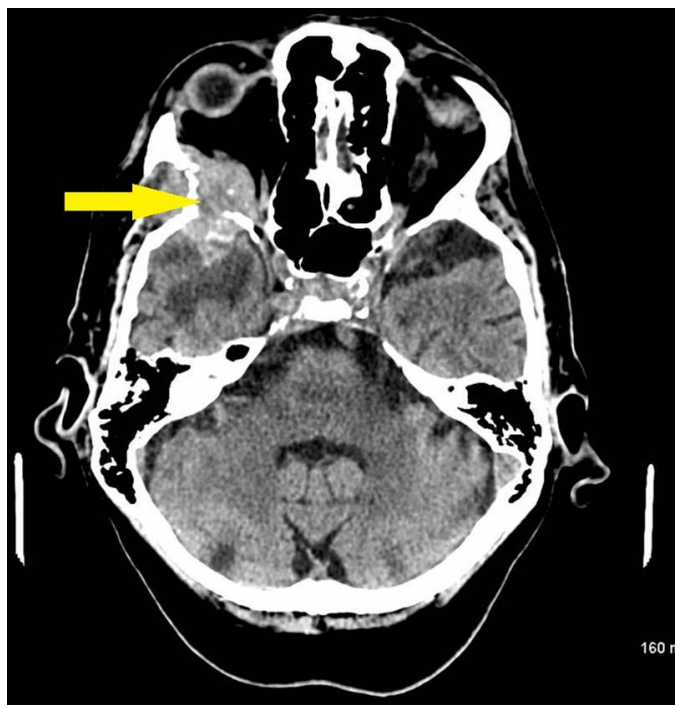

Figure $1 \mathrm{CT}$ of the brain showing a soft tissue mass on the posterior aspect of the right orbit with bony destruction of the greater wing of sphenoid.

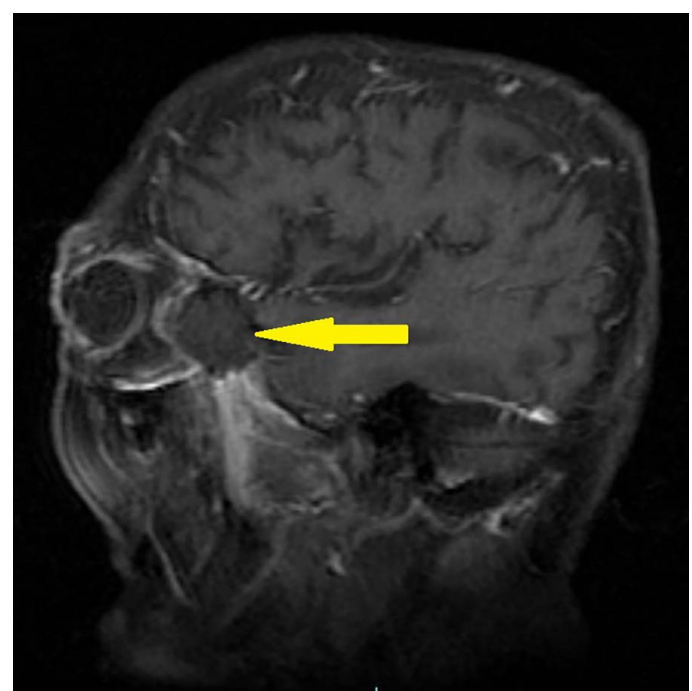

Figure $2 \mathrm{CT}$ of the brain showing a soft tissue mass on the posterior aspect of the right orbit with bony destruction of the greater wing of sphenoid.

most common source in different case series. The orbit is the second most common area of unusual metastasis from prostate cancer, atypical lymph node metastasis being the first (figure 3 ). ${ }^{2}$ In that report, the mean age of the patients was 70.5 years (range 60-90 years). The left and right orbits were both involved at a similar frequency, with bilateral involvement in some cases. The mean time period between the prostate cancer diagnosis and the orbital metastasis was 3.7 years (range $1-8$ years). On a few occasions, orbital metastasis was the presenting symptom of prostate cancer. PSA levels may be within normal range at the time of first manifestation of metastatic disease. ${ }^{3}$ CT scan is the imaging study of choice, and MRI is also very sensitive. Radiotherapy and steroids were used simultaneously as palliative therapy. Except for one case, all the patients expired within 1 year of metastasis.

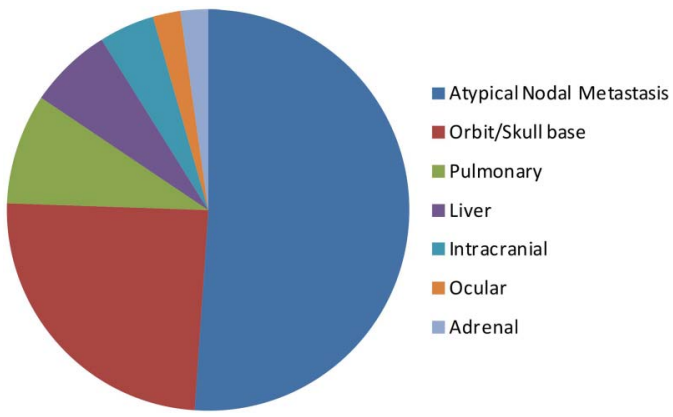

Figure 3 Distribution of atypical metastasis from prostate cancer. 


\section{Learning points}

- Orbital metastasis may present with proptosis and should be considered in patients with a history of cancer.

- Steroids and radiotherapy are the most beneficial palliative treatment.

- A normal prostate-specific antigen level is not uncommon and may add further diagnostic dilemma in cases of subtle metastatic disease.
Competing interests None declared.

Patient consent Obtained.

Provenance and peer review Not commissioned; externally peer reviewed.

\section{REFERENCES}

1 Tijl J, Koornneef L, Eijpe A, et al. Metastatic tumors to the orbit-management and prognosis. Graefes Arch Clin Exp Ophthalmol 1992;230:527-30.

2 Long MA, Husband JE. Features of unusual metastases from prostate cancer. $\mathrm{Br} J$ Radiol 1999;72:933-41.

3 Croxatto JO, Karcioglu ZA. Metastatic tumors. In: Karcioglu ZA, ed. Orbital tumors: diagnosis and treatment. 2nd edn. New York: Springer Science+Business Media, 2015.

Copyright 2015 BMJ Publishing Group. All rights reserved. For permission to reuse any of this content visit http://group.bmj.com/group/rights-licensing/permissions.

BMJ Case Report Fellows may re-use this article for personal use and teaching without any further permission.

Become a Fellow of BMJ Case Reports today and you can:

- Submit as many cases as you like

- Enjoy fast sympathetic peer review and rapid publication of accepted articles

- Access all the published articles

- Re-use any of the published material for personal use and teaching without further permission

For information on Institutional Fellowships contact consortiasales@bmjgroup.com

Visit casereports.bmj.com for more articles like this and to become a Fellow 